\title{
HUBUNGAN KEMAMPUAN AWAL TERHADAP KEMAMPUAN BERPIKIR KRITIS MATEMATIKA PADA SISWA KELAS VII SMP PESANTREN IMMIM PUTRI MINASATENE
}

\author{
RELATIONSHIP OF INITIAL CAPACITY CRITICAL THINKING ABILITY IN MATHEMATICS \\ Class VII SMP BoARding IMMiM PuTRi Minasatene
}

\author{
Firdha Razak \\ Pendidikan Matematika, STKIP Andi Matappa \\ firdarazak@yahoo.com
}

\begin{abstract}
Abstrak
Jenis penelitian ini adalah penelitian Ex-post facto yang bertujuan untuk mengetahui ada tidaknya hubungan kemampuan awal terhadap kemampuan berpikir kritis matematika pada siswa kelas VII SMP Pesantren IMMIM Putri Minasatene. Populasi dalam penelitian ini adalah seluruh siswa kelas VII SMP Pesantren IMMIM Putri Minasatene dan sampel penelitian adalah siswa kelas VII.II yang ditentukan dengan teknik purposive sampling. Instrumen yang digunakan adalah tes kemampuan awal dan tes kemampuan berpikir kritis kemudian dianalisis dengan korelasi product moment dari pearson. Berdasarkan hasil analisis diperoleh nilai koefisien korelasi $r_{x y}=0,748$ dan nilai $r=1$, kemudian nilai sig. $=0,001$. Dimana pada nilai tersebut berada pada interval koefisien 0,600 - 0,799 dengan tingkat hubungan yang kuat dan nilai $r=1$ artinya korelasinya sangat kuat dengan arah yang positif. Kemudian nilai sig. $=0,000$ sehingga nilai Sig. $<$ 0,05 atau 0,001 < 0,05 maka ada korelasi yang signifikan berarti $\mathrm{HO}$ ditolak dan $\mathrm{H} 1$ diterima yaitu ada hubungan antara kemampuan awal terhadap kemampuan berpikir kritis matematika pada siswa SMP Pesantren IMMIM Putri Minasatene.

Kata Kunci: Kemampuan Awal Siswa dan Kemampuan Berpikir Kritis Matematika Pada Siswa.
\end{abstract}

\begin{abstract}
This type of research is Ex-post facto research that aims to determine whether there is a relationship prior knowledge of the critical thinking skills of mathematics in class VII student Pesantren Putri IMMIM Minasatene. The population in this study were all students of class VII IMMIM Pesantren Putri Minasatene and the sample is grades VII.II determined by purposive sampling. The instrument used initial capability test and test the ability of critical thinking skills and then analyzed with Pearson product moment correlation. Based on the results obtained by analysis of the correlation coefficient $r x y=0.748$ and $r=1$, then sig. $=0.001$. Which at that point is in the interval coefficient from 0.600 to 0.799 with a degree of strong relationships and the value of $r=1$ means that the correlation is very strong with a positive direction. Then sig. $=0,000$ so that the Sig. $<0.05$ or $0.001<0.05$, no significant correlation mean $\mathrm{HO}$ rejected and $\mathrm{H} 1$ accepted that there is a relationship between prior knowledge of the critical thinking skills of mathematics at the junior high school students Pesantren Putri IMMIM Minasatene.

Keyword: Initial Capability Students and Critical Thinking Ability of Mathematics On Students.
\end{abstract}




\section{Pendahuluan}

Pendidikan adalah usaha sadar dan terencana untuk mewujudkan suasana belajar dan proses pembelajaran agar peserta didik secara aktif mengembangkan potensi dirinya untuk memiliki kekuatan spiritual, keagamaan, pengendalian diri, kecerdasan, akhlak mulia, serta keterampilan yang diperlukan dirinya, masyarakat, bangsa dan negara. Oleh karena itu, pendidikan memiliki peranan yang sangat penting dalam kehidupan manusia, karena pendidikan dapat mempengaruhi perkembangan manusia dalam seluruh aspek kepribadian dan kehidupan serta memiliki kekuatan yang sangat dinamis terhadap perkembangan intelektual. Semakin tinggi kemajuan pendidikan suatu bangsa maka akan semakin tinggi pula peradaban dan kesejahteraan bangsa tersebut. Pendidikan sesungguhnya bukan sematamata sebagai sarana untuk menjadikan individu bagi kehidupan masa depannya, tetapi yang terpenting adalah menciptakan dan membangun potensi serta sumber daya manusia anak didik yang unggul, yang dapat membangun dan memajukan negara dan bangsa yang dimulai dari proses pembelajaran dalam pendidikan.

Namun demikian, upaya membekali peserta didik kemampuan berpikir kritis dalam pembelajaran matematika belum sepenuhnya di akomodasi oleh peserta didik disetiap tatap muka sebab peserta didik masih menghadapi banyak kendala yang berujung pada rendahnya kemampuan awal siswa dalam menguasai konsep pembelajaran itu sendiri. Sebab kemampuan awal siswa akan berhubungan pada proses pembelajaran. Oleh karena itu, kemampuan awal siswa merupakan prasyarat awal yang harus dimiliki siswa agar proses pembelajaran yang dilakukan siswa dapat berjalan dengan baik.

Setiap individu mempunyai kemampuan belajar yang berlainan. Kemampuan awal siswa adalah kemampuan yang telah dipunyai oleh siswa sebelum ia mengikuti pembelajaran yang akan diberikan. Kemampuan awal (entry behavior) ini menggambarkan kesiapan siswa dalam menerima pelajaran yang akan disampaikan oleh guru. Kemampuan awal siswa penting untuk diketahui oleh guru sebelum ia mulai dengan pembelajarannya, karena dengan demikian dapat diketahui : a) apakah siswa telah mempunyai atau pengetahuan yang merupakan prasyarat (prerequisite) untuk mengikuti pembelajaran; b) sejauh mana siswa telah mengetahui materi apa yang akan disajikan. Dengan mengetahui kedua hal tersebut, guru akan dapat merancang pembelajaran dengan lebih baik, sebab apabila siswa diberi materi yang telah diketahui maka mereka akan merasa cepat bosan.

Kemampuan lain yang di miliki siswa yaitu kemampuan berpikir kritis. Dimana kemampuan berpikir kritis penting bagi masa depan siswa, mengingat bahwa itu mempersiapkan siswa untuk menghadapi banyak tantangan yang akan muncul dalam hidup mereka, karier dan tanggung 
jawab pribadi mereka, ( Tsui, dalam Vieira, dkk 2011). Jadi, manfaat kemampuan berpikir kritis siswa dalam pembelajaran sangat besar peranannya dalam meningkatkan proses dan hasil belajar. Selain manfaat, kemampuan berfikir kritis siswa dalam pembelajaran juga mempunyai peranan sebagai bekal siswa untuk menghadapi masa depan. Akan tetapi perbedaan kemampuan awal siswa akan mempengaruhi tingkat penguasaan materi bahan pelajaran antara masingmasing siswa. Selain itu, kemampuan awal juga sangat menentukan dalam proses berpikir siswa dalam memahami dan mengetahui sebuah masalah yang diberikan. Kemampuan awal yang baik akan dapat menuntun siswa untuk lebih mudah dalam memahami persoalan matematika yang melibatkan kemampuan berpikir tingkat tinggi. Siswa yang memiliki kemampuan awal yang baik, tentunya memiliki potensi untuk melakukan proses berpikir tingkat tinggi atau berpikir kritis, karena telah memiliki pondasi pengetahuan yang cukup untuk melakukan olah pikir yang baik. Maka dari itu, kemampuan awal akan menentukan kemampuan berpikir kritis siswa dalam memecahkan masalah matematika yang dihadapinya.

Berdasarkan hasil observasi dan pengamatan langsung dalam pembelajaran matematika yang dilakukan di SMP Pesantren Immim Minasatene tahun 2015, masih ada siswa yang tidak berani dalam mengemukakan pendapat atau pertanyaannya walaupun guru telah memberikan kesempatan untuk berpendapat atau bertanya. Bahkan masih ada juga siswa yang malas mengerjakan soal latihan ataupun PK (Pekerjaan Kamar) yang telah diberikan oleh guru. Kondisi seperti itu disebabkan karena kemampuan awal dan kemampuan berpikir kritis siswa yang berbeda-beda. Sehingga siswa yang kemampuan awalnya masih kurang ataupun sedang sering kali hanya menunggu jawaban dari temannya atau guru karena mereka merasa kesulitan untuk berpikir kritis dalam memecahkan masalah matematika yang dihadapinya. Berdasarkan uraian di atas, maka peneliti mencoba mengangkat penelitian dengan judul "Hubungan Kemampuan Awal Terhadap Kemampuan Berpikir Kritis Matematika Pada Siswa Kelas VII SMP Pesantren Immim Minasatene".

Pembelajaran merupakan suatu kegiatan untuk membelajarkan para siswa, artinya membuat para siswa mau belajar. Setiap individu mempunyai kemampuan belajar yang berlainan. Menurut Mohammad Syarif Sumantri (2015:183) mengemukakan bahwa "Kemampuan awal siswa adalah kemampuan yang telah dipunyai oleh siswa sebelum ia mengikuti pembelajaran yang akan diberikan". Kemudian menurut Atwi Suparman (dalam Budi Wahyono, 2013) mengemukakan bahwa "kemampuan awal adalah pengetahuan dan keterampilan yang telah dimiliki siswa sehingga mereka dapat mengikuti pelajaran dengan baik. Sedangkan menurut Winkel (dalam Budi Wahyono, 2013) mengemukakan bahwa 
"kemampuan awal merupakan jembatan untuk menuju pada kemampuan final. Setiap proses pembelajaran mempunyai titik tolaknya sendiri atau berpangkal pada kemampuan awal siswa tertentu untuk dikembangkan menjadi kemampuan baru, setiap apa yang menjadi tujuan dalam proses pembelajaran."

Kemampuan awal siswa penting untuk diketahui guru sebelum ia mulai dengan pembelajarannya, karena dengan demikian dapat diketahui: a) apakah siswa telah mempunyai atau pengetahuan yang merupakan prasyarat (prerequisite) untuk mengikuti pembelajaran; b) sejauh mana siswa telah mengetahui materi apa yang akan disajikan. Dengan mengetahui kedua hal tersebut, guru akan dapat merancang pembelajaran dengan lebih baik, sebab apabila siswa diberi materi yang telah diketahui maka mereka akan merasa cepat bosan. Kemampuan awal siswa dapat berfungsi untuk mempermudah dan mengoptimalkan perolehan, pengorganisasian dan mengungkap kembali pengetahuan baru (hasil belajar) seseorang.

Berdasarkan uraian di atas dapat disimpulkan bahwa kemampuan awal siswa adalah suatu kemampuan yang telah dimiliki sebelum pembelajaran berlangsung yang merupakan prasyarat untuk mengikuti proses belajar selanjutnya. Kemampuan awal berperan penting dalam proses pembelajaran. Kemampuan awal juga menggambarkan kesiapan siswa dalam menerima materi pelajaran baru yang akan diberikan oleh guru pada kelas yang lebih tinggi.

Berpikir merupakan sebuah aktifitas manusia dalam menerjemahkan sesuatu kedalam kerangka otak atau pengetahuan yang dimiliki. Kegiatan ini melibatkan organ manusia yang paling penting yaitu otak.

Menurut Garret (dalam Diana Martiana, 2015) mengemukakan bahwa "berpikir adalah perilaku yang sering kali tersembunyi atau setengah tersembunyi di dalam ide dan konsep yang dilakukan seseorang". Ketika seseorang sedang berpikir seringkali tidak dapat dilihat oleh orang lain tetapi dapat diukur dari hasil ide atau konsep yang dilakukan. Sedangkan menurut Mayadiana (dalam Diana Martiana, 2015) menyatakan bahwa "berpikir adalah suatu kekuatan mental untuk memperoleh pengetahuan"

Menurut Kamus Besar Bahasa Indonesia (2006:534) "berpikir adalah menggunakan akal budi untuk menemukan jalan keluar, mempertimbangkan atau memutuskan sesuatu; menimbang-nimbang dalam hati". Kemudian Menurut Iskandar (dalam Kate13, 2014) mengemukakan bahwa:

Kemampuan berpikir merupakan kegiatan penalaran yang reflektif, kritis, dan kreatif,yang berorientasi pada suatu proses intelektual yang melibatkan pembentukan konsep (conceptualizing), aplikasi, analisis, menilai informasi yang terkumpul (sintesis) atau dihasilkan melalui pengamatan, pengalaman, refleksi, 
komunikasi sebagai landasan kepada suatu keyakinan (kepercayaan) dan tindakan.

Berdasarkan uraian di atas dapat disimpulkan bahwa berpikir adalah sebuah aktivitas manusia dalam mengolah suatu informasi sehingga menghasilkan suatu pengetahuan atau keputusan yang akan digunakan dalam menyelesaikan suatu masalah.

Berpikir kritis merupakan kemampuan untuk mengevaluasi secara sistematis bobot pendapat pribadi dan pendapat orang lain. Selanjutnya

Arti kritis menurut Kamus Besar Bahasa Indonesia (2006:396) yaitu:

1. Gawat, genting, dalam keadaan krisis; keadaan yang paling menentukan berhasil atau gagalnya suatu usaha

2. Tajam dalam mengkritisi.

Menurut Robert Ennis (dalam Fisher, 2009:4) menyatakan bahwa "berpikir kritis merupakan pemikiran yang masuk akal dan reflektif yang berfokus untuk memutuskan apa yang mesti dipercaya atau dilakukan". Sedangkan menurut Fisher (2009:4) mengemukakan bahwa "berpikir kritis adalah mode berpikir mengenai hal, substansi atau masalah apa saja, dimana si pemikir meningkatkan kualitas pemikiriannnya dengan menangani secara terampil strukturstruktur yang melekat dalam pemikiran dan menerapkan standar-standar intelektual".

Menurut Baron dan Stemberg (dalam Dasa Ismaimuza, 2011) terdapat lima hal dasar dalam "berpikir kritis yaitu praktis, reflektif, masuk akal, keyakinan, dan tindakan. Dari penggabungan lima hal dasar ini maka didefinisikan bahwa berpikir kritis itu adalah suatu pikiran reflektif yang difokuskan untuk memutuskan apa yang diyakini untuk dilakukan". Sejalan dengan itu Marzano et al (dalam Dasa Ismaimuza, 2011) mengungkapkan bahwa "berpikir kritis adalah sesuatu yang masuk akal, berpikir reflektif yang difokuskan pada apa keputusan yang diyakini, dikerjakan, dan diperbuat".

Jadi, berpikir kritis adalah sebuah pemikiran yang genting dimana memerlukan pemahaman yang tinggi dan penganalisaan yang tajam.

Kemampuan berpikir kritis matematika adalah kemampuan berpikir dalam menyelesaikan masalah matematika yang melibatkan pengetahuan matematika, penalaran matematika dan pembuktian matematika.

Menurut Krulik dan Rudnick (dalam Somakim, 2011) mengemukakan bahwa "yang termasuk berpikir kritis dalam matematika adalah berpikir yang menguji, mempertanyakan, menghubungkan, mengevaluasi semua aspek yang ada dalam suatu situasi ataupun suatu masalah". Sedangkan Glazer (dalam Diana Martiana, 2015) merumuskan "berpikir kritis dalam matematika sebagai kemampuan untuk menyertakan pengetahuan sebelumnya, penalaran matematika dan strategi kognitif untuk mengeneralisasi, membuktikan atau 
mengevaluasi situasi-situasi matematika yang tidak familiar".

Berdasarkan beberapa definisi di atas, maka dapat disimpulkan bahwa kemampuan berpikir kritis matematika adalah suatu kemampuan yang dimiliki berupa pemikiran yang sangat genting dimana memerlukan pemahaman, pengevaluasian, dan penganalisaan yang sangat tajam dalam menyelesaikan soalsoal matematika yang dihadapinya.

\section{Metode}

Pendekatan penelitan yang digunakan adalah pendekatan kuantitatif dengan jenis penelitian Expost facto yang bertujuan untuk mengetahui apakah kemampuan awal siswa memiliki hubungan dengan kemampuan berpikir kritis matematika pada siswa dan instrumen yang digunakan adalah tes. Pada penelitian ini digunakan dua variabel sebagai titik tolak untuk menganalisa atau menguji hipotesis yaitu variabel bebas berupa kemampuan awal dan variabel terikat berupa kemampuan berpikir kritis matematika. Adapun desain penelitiannya adalah sebagai berikut:

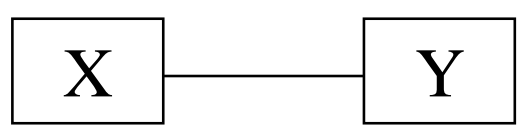

Keterangan :

$X$ : Kemampuan awal siswa

$Y$ : Kemampuan berpikir kritis matematika

Populasi dalam penelitian ini adalah seluruh siswa kelas VII SMP Pesantren Immim Minasatene. Adapun yang menjadi sampel dalam penelitian ini yaitu kelas VII Il yang terdiri dari 20 siswa dengan teknik pengambilan sampel yang digunakan adalah sampling purposive.. Teknik analisis meliputi analisis statistik deskriptif dan analisis statistik infrensial.

Pada analisis statistik deskriptif, adapun pengkategorian kemampuan awal siswa menurut Abdorrakhman Gintings (dalam Amriati 2015) sebagai berikut :

Tabel 1.

Kategori Penilaian Kemampuan Awal Siswa

\begin{tabular}{|cc|}
\hline \multicolumn{1}{c}{ Skor hasil belajar } & Kategori \\
\hline $80-100$ & Sangat Baik \\
\hline $68-79$ & Baik \\
\hline $55-67$ & Cukup / Sedang \\
\hline $45-54$ & Kangang \\
\hline$<45$ & \\
\hline
\end{tabular}

Selanjutnya, data isian tes kemampuan berpikir kritis matematika pada siswa dianalisis dengan cara menghitung persentase kemampuan berpikir kritis siswa. Menurut Suharsimi Arikunto (2008) menyatakan bahwa pembagian kategori kemampuan berpikir kritis belajar setelah dimodifikasi adalah sebagai berikut : 
Tabel 2.

Kategori Tingkat Kemampuan Berpikir Kritis Belajar Siswa

\begin{tabular}{|cc|}
\hline $\begin{array}{l}\text { Rentang persentase hasil kemampuan } \\
\text { berpikir kritis belajar metematika (\%) }\end{array}$ & Kategori \\
\hline $80 \leq P \leq 100$ & Sangat Baik \\
\hline $65 \leq P \leq 79,99$ & Baik \\
\hline $55 \leq P \leq 64,99$ & Cukup / Sedang \\
\hline $40 \leq P \leq 54,99$ & Kurang \\
\hline $0 \leq P \leq 39,99$ & Sangat Kurang \\
(sumber : Arikunto. Dasar-dasar evaluasi pendidikan hal.251)
\end{tabular}

Analisis hasil tes kemampuan berpikir kritis belajar siswa dilakukan dengan cara sebagai berikut:

1. Menghitung jumlah skor dengan acuan pedoman penskoran yang telah ditetapkan.

2. Menjumlahkan skor kemudian menghitung persentase tes kemampuan berpikir kritis belajar dengan menggunakan rumus:

Persentase $=$ $\frac{\text { jumlah skor }}{\text { jumlah skor maksimal }} \times 100 \%$

3. Setelah mendapatkan persentase hasil tes kemampuan berpikir kritis belajar siswa, dilakukan pemberian kategori skor tentang kemampuan berpikir kritis belajar metematika siswa.

Pada analisis inferensial menggunakan analisis korelasi. Model korelasi yang digunakan adalah korelasi Product Moment dengan menggunakan bantuan SPSS versi 21 for windows.

$$
r_{x y}=\frac{\sum x y}{\sqrt{\left(\sum x^{2}\right)\left(\sum y^{2}\right)}}
$$

(Sugiyono, 2012:255).

Keterangan :

$r_{x y}$ : koefisien korelasi dari variabel $x$ dan $y$

$=\quad \sum x y$ : jumlah dari hasil kali variabel $x$ dan variabel $y$

$\sum x^{2}$ : jumlah variabel $x$ yang dikuadratkan

$\sum y^{2}$ : jumlah variabel $y$ yang dikuadratkan

Adapun pedoman untuk memberikan interpretasi terhadap koefisien korelasi menurut Sugiyono (2012:257) adalah sebagai berikut:

Tabel 3.

Pedoman untuk memberikan interpretasi terhadap koefisien korelasi

\begin{tabular}{|cc|}
\hline Inteval koefisien & Tingkat Hubungan \\
\hline $0,000-0,199$ & Sangat rendah \\
\hline $0,200-0,399$ & Rendah \\
\hline $0,400-0,599$ & Sedang \\
\hline $0,600-0,799$ & Kuat \\
\hline $0,800-1,000$ & Sangat kuat \\
\hline
\end{tabular}

III. Hasil dan Pembahasan A. Hasil Analisis Statistik Deskriptif
Hasil analisis statistik deskriptif berdasarkan skor yang telah diperoleh 
pada masing-masing variabel penelitian yaitu kemampuan awal dan kemampuan berpikir kritis matematika pada siswa kelas VII.II SMP Pesantren IMMIM Putri Minasatene adalah sebagai berikut:
1. Hasil analisis deskriptif terhadap kemampuan awal siswa kelas VII.II SMP Pesantren IMMIM Putri Minasatene adalah sebagai berikut:

Tabel 4.

Hasil Analisis Deskriptif Kemampaun Awal Siswa Kelas VII.„SMP Pesantren IMMIM Putri Minasatene

\begin{tabular}{|cc|}
\hline Statistik & Nilai Statistik \\
\hline Jumlah siswa & 20 \\
\hline Mean & 66.32 \\
\hline Median & 68.42 \\
\hline Modus & 58.00 \\
\hline Std. Deviasi & 12.242 \\
\hline Varians & 149.876 \\
\hline Range & 42.00 \\
\hline Minimum & 42.00 \\
\hline Maksimum & 84.00 \\
\hline Sum & 1326.00 \\
\hline
\end{tabular}

Sumber: Hasil Analsis Data 2016

Pada tabel 4 menunjukkan bahwa tingkat hasil belajar matematika sebagai kemampuan awal siswa SMP Pesantren IMMIM Putri Minasatene berada dalam kategori cukup atau sedang.
2. Hasil analisis deskriptif terhadap kemampuan berpikir kritis matematika pada siswa kelas VII.II SMP Pesantren IMMIM Putri Minasatene adalah sebagai berikut:

Tabel 5.

Hasil Analisis Deskriptif Kemampuan Berpikir Kritis Matematika Siswa Kelas VII. IMP Pesantren IMMIM Putri Minasatene

\begin{tabular}{|cc|}
\hline Statistik & Nilai Statistik \\
\hline Jumlah siswa & 20 \\
\hline Mean & 41.72 \\
\hline Median & 41.38 \\
\hline Modus & 41.00 \\
\hline Std. Deviasi & 15.619 \\
\hline Varians & 243.945 \\
\hline Range & 66.00 \\
\hline Minimum & 17.00 \\
\hline Maksimum & 83.00 \\
\hline Sum & 834.00 \\
\hline
\end{tabular}

Pada tabel 5 menunjukkan bahwa tingkat hasil belajar matematika sebagai kemampuan awal siswa SMP Pesantren IMMIM Putri 
Minasatene kemampuan berpikir kritis matematika pada siswa kelas VII.| SMP Pesantren IMMIM Putri Minasatene berada dalam kategori sangat kurang.

\section{B. Hasil Analisis Inferensial}

1) Uji Normalitas
Uji Normalitas dilakukan terhadap nilai masing-masing kelompok dengan tujuan untuk mengetahui apakah sampel penelitian berasal dari populasi yang berdistribusi normal atau tidak. Seluruh analisisnya dilakukan dengan menggunakan bantuan komputer dengan program SPSS versi 21 dengan uji Kolmogorov-Smirnov.

Tabel 6.

Hasil Uji Normalitas Data

\begin{tabular}{|lcccc}
\hline \multicolumn{1}{c}{} & \multicolumn{3}{c}{ Kolmogorov-Smirnov $^{\text {a }}$} \\
\cline { 2 - 5 } \multicolumn{1}{c}{} & Statistic & Df & \multicolumn{2}{c}{ Sig. } \\
\hline Kemampuan Awal & & 20 & .200 \\
\hline Kemampuan Berpikir Kritis & .154 & 20 & .064 \\
\hline Kemampuan Awal & .187 & 20 & .200 \\
\hline
\end{tabular}

Berdasarkan hasil analisis data di atas, menunjukkan bahwa nilai uji normalitas untuk kemampuan awal dengan menggunakan uji Kolmogorov-Smirnov sebesar 0.200 dengan taraf signifikansi 0.05, nilai ini menunjukkan bahwa nilai probabilitas (sig) yaitu 0,200, 0,05 yang berarti bahwa data yang diperoleh termasuk dalam kategori normal. Sedangkan untuk nilai kemampuan berpikir kritis matematika dengan menggunakan uji Kolmogorov-Smirnov sebesar 0.064 dengan taraf signifikansi 0.05, nilai ini menunjukkan bahwa nilai probabilitas (sig) yaitu 0,064, 0,05 yang berarti bahwa data yang diperoleh juga termasuk dalam kategori normal. Hal ini menunjukkan bahwa nilai sampel berasal dari populasi yang termasuk kategori normal.

2) Uji Hipotesis
Dalam penelitian ini diajukan hipotesis yang diuji dengan menggunakan statistik inferensial melalui korelasi product moment dari pearson. Korelasi dilakukan untuk mengetahui ada tidaknya hubungan antara kedua variabel penelitian yang diteliti. Hipotesis yang diajukan adalah "Ada hubungan antara kemampuan awal terhadap kemampuan berpikir kritis matematika pada siswa SMP Pesantren IMMIM Putri Minasatene"

Untuk keperluan analisis hipotesis dirumuskan sebagai berikut:

$\mathrm{HO}: p=0$

$\mathrm{H} 1: p \neq 0$

HO : Tidak ada hubungan kemampuan awal terhadap kemampuan berpikir kritis matematika pada siswa kelas VII SMP Pesantren Immim Minasatene

H1: Ada hubungan kemampuan awal terhadap kemampuan berpikir kritis 
matematika pada siswa kelas VII SMP Pesantren Immim Minasatene

Tabel 7.

Hasil Uji Korelasi Pearson

\begin{tabular}{llrr}
\hline & & Kemampuan Awal & \multicolumn{1}{c}{$\begin{array}{c}\text { Kemampuan } \\
\text { Berpikir Kritis }\end{array}$} \\
\hline \multirow{3}{*}{ Kemampuan Awal } & Pearson Correlation & 1 & .748 \\
\cline { 2 - 4 } & Sig. (2-tailed) & 20 & .001 \\
\cline { 2 - 4 } & $\mathrm{N}$ & .748 & 20 \\
\hline Kemampuan Berpikir Kritis & Pearson Correlation & .001 & 1 \\
\cline { 2 - 4 } & Sig. (2-tailed) & 20 & 20 \\
\cline { 2 - 4 } & $\mathrm{N}$ & & \\
& &
\end{tabular}

Pada tabel 7 di atas dapat dilihat bahwa hasil uji korelasi pearson antara pasangan data kemampuan awal terhadap kemampuan berpikir kritis matematika, diperoleh nilai koefisien korelasi $r x y=$ 0,748 dan nilai $r=1$, kemudian nilai sig. $=$ 0,001 . Berdasarkan tabel 3.3 pedoman untuk memberikan interpretasi terhadap koefisien korelasi, di mana pada nilai koefisien korelasi $r x y=0,748$ berada pada interval koefisien 0,600 - 0,799 dengan tingkat hubungan yang kuat dan nilai $r=1$ artinya korelasinya sangat kuat dengan arah yang positif. Kemudian untuk pengambilan keputusan statistik hipotesis dilakukan dengan cara melihat nilai signifikansinya, apabila nilai Sig. < 0,05 maka ada korelasi yang signifikan ( $\mathrm{H} 1$ diterima), tetapi apabila nilai Sig. > 0,05 maka tidak ada korelasi yang signifikan ( $\mathrm{HO}$ diterima). Berdasarkan hasil uji korelasi pearson antara pasangan data kemampuan awal terhadap kemampuan berpikir kritis matematika, diperoleh nilai sig. = 0,000. Sehingga, nilai Sig. < 0,05 atau $0,000<0,05$ maka ada korelasi yang signifikan berarti $\mathrm{HO}$ ditolak dan $\mathrm{H} 1$ diterima. Jadi, Ada hubungan antara kemampuan awal terhadap kemampuan berpikir kritis matematika pada siswa SMP Pesantren IMMIM Putri Minasatene.

\section{Pembahasan}

Berdasarkan hasil analisis data penelitian yang telah dipaparkan terlihat bahwa rata-rata hasil belajar siswa pada tes kemampuan awal yang dilakukan di kelas VII.II SMP Pesantren IMMIM Putri Minasatene memiliki nilai rata-rata sebesar 66,32 dari jumlah sampel sebanyak 20 orang siswa, dimana pada nilai tersebut berada pada kategori cukup atau sedang, yang berarti bahwa hanya sebagian siswa yang telah memiliki kemampuan awal yang baik, dan yang lainnya masih sedang bahkan masih adapula yang kurang.

Pada hasil analisis data tentang kemampuan berpikir kritis matematika pada siswa yang diberikan dengan jumlah soal sebanyak tiga nomor, dapat dilihat bahwa nilai rata-rata hasil belajar siswa memiliki rata-rata sebesar 41,72 dari jumlah sampel sebanyak 20 orang siswa, di mana pada nilai tersebut berada pada kategori sangat kurang, yang berarti 
sebagian besar siswa memiliki kemampuan berpikir kritis matematika yang sangat kurang. Sehingga masih banyak siswa yang memerlukan pembinaan yang lebih baik untuk meningkatkan kemampuan berpikir kritisnya.

Sedangkan hasil uji hipotesis menunjukkan bahwa terdapat hubungan yang "kuat" antara kedua variabel yaitu variabel kemampuan awal dan kemampuan berpikir kritis matematika. Berdasarkan dari uji korelasi yang telah dilakukan menunjukkan bahwa nilai koefisien korelasi $r x y=0,748$. Di mana pada nilai tersebut berada pada interval koefisien 0,600 - 0,799 dengan tingkat hubungan yang kuat dan nilai $r=1$ artinya korelasinya sangat kuat dengan arah yang positif. Kemudian nilai sig. $=0,000$ sehingga nilai Sig. $<0,05$ atau 0,000 < 0,05 maka ada korelasi yang signifikan berarti HO ditolak dan H1 diterima. Jadi ada hubungan antara kemampuan awal terhadap kemampuan berpikir kritis matematika pada siswa kelas VII SMP Pesantren Immim Minasatene.

Maka dari itu, dapat disimpulkan bahwa siswa yang memiliki kemampuan awal yang sedang ataupun kurang, juga akan memiliki kemampuan berpikir kritis yang kurang atau sangat kurang begitupun sebaliknya. Selain itu terlihat dari hasil uji kemampuan awal dan kemampuan berpikir kritis terdapat sebagian besar siswa yang memiliki kemampuan awal yang sedang ataupun kurang juga memiliki kemampuan berpikir kritis yang kurang atau sangat kurang tetapi ada juga siswa yang memiliki kemampuan awal yang baik juga memiliki kemampuan berpikir kritis yang baik pula. Hal ini sesuai dengan teori yang dikemukakan oleh Winkel (dalam Budi Wahyono, 2013) bahwa "kemampuan awal merupakan jembatan untuk menuju pada kemampuan final. Setiap proses pembelajaran mempunyai titik tolaknya sendiri atau berpangkal pada kemampuan awal siswa tertentu untuk dikembangkan menjadi kemampuan baru, setiap apa yang menjadi tujuan dalam proses pembelajaran".

\section{Penutup}

Berdasarkan hasil analisis data dan pembahasan maka dapat ditarik beberapa kesimpulan sebagai berikut:

1. Kemampuan awal siswa kelas VII.II SMP Pesantren IMMIM Putri Minasatene memiliki nilai rata-rata sebesar 66,32 di mana pada nilai tersebut berada pada kategori cukup atau sedang.

2. Kemampuan Berpikir kritis siswa kelas VII.II SMP Pesantren IMMIM Putri Minasatene memiliki ratarata sebesar 41,72 di mana pada nilai tersebut berada pada kategori sangat kurang.

3. Ada hubungan yang kuat antara kemampuan awal siswa terhadap kemampuan berpikir kritis matematika pada siswa kelas VII SMP Pesantren IMMIM Putri Minasatene. Hal ini ditunjukkan berdasarkan dari uji korelasi yang telah dilakukan, terlihat bahwa nilai 
koefisien korelasi $r x y=0,748$. Di mana pada nilai tersebut berada pada interval koefisien 0,600 0,799 dengan tingkat hubungan yang kuat dan nilai $r=1$ artinya korelasinya sangat kuat dengan arah yang positif. Kemudian nilai sig. = 0,000 sehingga nilai Sig. < 0,05 atau 0,000 < 0,05 maka ada korelasi yang signifikan berarti $\mathrm{HO}$ ditolak dan $\mathrm{H} 1$ diterima.

\section{Daftar Pustaka}

Alec Fisher, 2009, Berpikir kritis Sebuah pengantar, Erlangga, Jakarta

Budi Wahyono, 2013, Kemampuan Awal Siswa, (online), http://www. pendidikanekonomi.com/2013/07/ke mampuanawaalsiswa.html?m=1,

(Diakses 24 April 2016)

Dasa Ismaimuza, 2011, Kemampuan

Berpikir Kritis Matematis Ditinjau dari Pengetahuan Awal Siswa, Jurnal, Volume 2 Nomor 1

Diana Martiana, 2015, Meningkatkan Kemampuan Berpikir Kritis Matematis Siswa Dengan Menggunakan Model Pembelajaran Kooperatif Tipe Team Assisted Individualization (TAI), Skripsi, Jurusan Pendidikan Matematika Fakultas IImu Tarbiyah Dan Keguruan, Universitas Islam Negeri Syarif Hidayatullah, Jakarta

Kasmadi, dkk, 2014, Panduan Modern Penelitian Kuantitatif, Alfabeta, Bandung

Kate13, 2014, pengertian kemampuan berpikir kritis, (online), http://www. kajianteori.com/2014/02/pengertiankemampuan-berpikir-kritis.html, (Diakses 03 Oktober 2015)

Mohammad Syarif Sumantri, 2015, Strategi Pembelajaran Teori dan Praktik di Tingkat Pendidikan Dasar, Raja Grafindo Persada, Jakarta

Somakim, 2011, Peningkatan Kemampuan

Berpikir Kritis Matematis Siswa Sekolah Menengah Pertama Dengan Penggunaan Pendidikan Matematika Realistik, Jurnal, Forum MIPA Volume 14 Nomor 1, (online), http://eprints.unsri.ac.id/1526/1/08-

Somakim_Matematika-(42-48).pdf,

(Diakses 24 Januari 2016)

Sugiyono, 2012, Metode Penelitian Pendidikan, Alfabeta, Bandung

Suharsimi Arikunto, 2008, Dasar- dasar Evaluasi Pendidikan (Edisi Revisi), Bumi Aksara, Jakarta

Umi Chulsum, dkk, 2006, Kamus Besar Bahasa Indonesia, Kashiko, Surabaya Vieira, dkk, 2011, Critical Thinking Conceptual Clarification and Its Importance in Science Education, Science Education Internasional, 22 (1), 43-54

Wiratna Sujarweni, 2014, SPSS Untuk Penelitian, Pustaka Baru Press, Yogyakarta. 